\title{
Analysis and Reflection on the New Trend of Development of Secretarial Science in China
}

\author{
Yao Yiran ${ }^{1}$ \\ ${ }^{1}$ Ph.D student of College of Arts, Jinan University, China \\ Correspondence: Yao Yiran. E-mail: 34644567@qq.com
}

\author{
Received: April 6, $2017 \quad$ Accepted: April 28, $2017 \quad$ Online Published: May 31, 2017 \\ doi:10.5539/ass.v13n6p142 URL: https://doi.org/10.5539/ass.v13n6p142
}

\begin{abstract}
Globalization, marketization, and structural reform have brought great changes to Chinese society, and have promoted transformation of the discipline of Secretarial Science in China towards internationalization, marketization, interdisciplinary, comprehensiveness at a high ranking. The thesis is aimed to present the current status of this discipline, and analyze the positive influence and possible problems brought by this new trend by comparison with foreign related experience.
\end{abstract}

Keywords: Secretarial Science, transformation, internationalization, interdiscipline, high-level development, Secretarial Science in South Korea

\section{The Tradition, Current Status, and New Trend of Secretarial Science in China}

The discipline of Secretarial Science in China rose in the $1980 \mathrm{~s}^{[1]}$, and was officially listed in the Undergraduate Specialty Catalogue of Higher Institutions by the Minister of Education in $2012^{[2]}$. Since the birth, it has been closely associated with secretarial work of the Party's and the Government's organs, and has featured a continuation of the characteristics of secretarial positions in ancient and modern Chinese bureaucratic system. Usually affiliated to the major of Chinese Language and Literature, the goal of this discipline is to cultivate secretarial talents for the Party's and the Government's organs as well as public institutions, especially focusing on students' abilities of writing articles, holding meetings, and handling affairs ${ }^{[3]}$. The primary courses are those of Chinese Language and Literature plus document writing.

Although the number of the universities which have the major or direction of Secretarial Science increases continuously during over thirty years, the nature and characteristics of this discipline has slightly changed. In China $95^{1}$ colleges have independent Secretarial Science major for undergraduates ${ }^{[4]}$, and more colleges have relevant directions, but these majors or directions, such as Secretarial Science, Secretarial Education, and Senior Secretary, are attached to the School of Chinese Language and Literature, which implies that problem that Secretarial Science hasn't been distinguished from the major of Chinese Language and Literature. As for undergraduate education, the major of Secretarial Science in many colleges are similar to that of Chinese Language and Literature, except for few courses ${ }^{2}$. The development of Secretarial Science is quite restricted due to exterior disadvantages ${ }^{3}$. It has lagged behind the rapid development of market-oriented economy and expansion of globalization. However, it also must be noticed that this discipline is undergoing new changes, which can be manifested as follows:

First, both consciousness and practice of interdiscipline has been enhanced. Shortly after the foundation of China, Secretarial Science was suggested to combine with other disciplines such as Psychology, Management, and Sociology. As early as 1986, the significance of Psychology to secretarial works has been recognized, and

\footnotetext{
1 1. Since 2012, up to 95 universities have Secretary Science in 2015.33 universities opened the major in 2012,33 universities in 2013 , 13 universities in 2014, and 16 universities in 2015, according to statistics in the website of Minister of Education.

2 2. It is based on the situation of Chinese Language and Literature in Jinan University, Zhuhai campus ( Senior Secretary), Chinese Language and Literature in Anhui Normal University(Secretary).

3 in "The First Chinese Secretarial Study Summit(Jinan) held from Oct, $26^{\text {th }}, 2016$ to Oct, $27^{\text {th }}$, 2016, many secretarial experts said that the discipline is restricted by teachers' academic background, while the teacher's advancement cannot be fulfilled in the discipline, and the professional title evaluation of teachers should be done in other disciplines such as Chinese Ancient Literature.
} 
psychological training was urged by Chinese scholars ${ }^{[5]}$. Afterwards, Some scholars proposed the idea of exploring and establishing "Secretarial Psychology"[6]. Since 1990, especially after 2010, a few textbooks on "Secretarial Psychology" has been published ${ }^{[7][8][9]}$, along with thesis covering teaching of Secretarial Psychology ${ }^{[10]}$, the relationship between the leader and the secretary from the perspective of Secretarial Psychology ${ }^{[11]}$, the EQ of secretaries ${ }^{[12]}$, etc.

Some scholars believe that Secretarial Science owns similar disciplinary attributes as Management ${ }^{[13][14]}$, and have argued strongly for establishment of auxiliary management system since the year of $1999^{4}$. Some scholars think that Secretarial Science should be a interdisciplinary subject of Chinese Language and Literature and Administrative Management ${ }^{[16]}$. However, the analysis of interdisciplinary feature of Secretarial Science from the perspective of Management takes up the most, like the theory of Secretary Obedience, time management techniques ${ }^{[18]}$, and the relationship between the boss and the secretary ${ }^{[19]}$, etc. Some advocate that we should

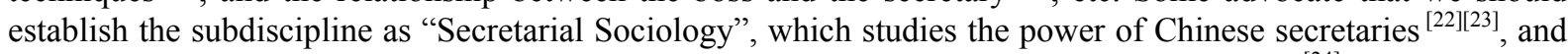
some think that this discipline should become more interdisciplinary with international insight ${ }^{[24]}$.

Course construction is a wonderful embodiment of increasing consciousness of interdisciplinary development of Secretary Science. Currently many colleges and institutions have management courses and psychological courses for students majoring in Secretarial Science. As the trend of internalization speeds up, the Senior Secretary and Administrative Assistant specialty in Jinan University opens a doctoral course "An Introduction to International Affairs", which is the fruit of internationalization and interdisciplinary trend.

Second, the direction of Secretarial Science is more diversified and the educational objective is expanded. The discipline was merely Secretarial Science or Secretary at the beginning, but now a variety of majors or directions can be found in Chinese universities, such as Secretary, Senior Secretary and Administrative Assistant, Secretary Mastering Chinese and English, Senior Foreign-Related Secretary, Senior Secretary, Senior Clerk, Commercial Secretary, etc ${ }^{5}$. Such change of titles implies transformation of educational objective from the secretaries who are specialized in writing documents for the government and public institutions to the administrative assistants and secretaries who have comprehensive abilities and multi-disciplinary knowledge for the society, which largely exceeds the traditional training goal in China.

Third, the educational level is progressively upgraded. After over thirty years' development, Secretarial Science has transformed from a major in junior colleges, self-study undergraduate course, then a direction affiliated to undergraduate majors $^{[25]}$, and finally a dependent undergraduate major in 2012. Since 2005, many colleges like Shanxi Normal University, Nanjing Normal University, and Zhengzhou University have set up Secretary Science and "the specialty of Secretary" for postgraduates under the discipline of Linguistics and Theory of Literature and Art, etc $^{6}$. In 2008, Jinan University established the Major of Senior Secretary and Administrative Assistant for postgraduate study, and it became a independent M.A program and Doctor program in 2013, and the first $\mathrm{PhD}$ student was enrolled into the university. Meanwhile, the course structure and teaching mode are quite different from that of traditional Secretarial Science specialty. The major of Senior Secretary in Jinan University opens the courses like Organizational Behavior and An Introduction to International Affairs, which combine the interdisciplinary practice with internationalization. Moreover, the university established the tutor-responsible system outside the school, to pace up combination of teaching with practice. Apart from Jinan University, some universities like Zhengzhou University and Anhui Normal University have established independent M.A program of Secretarial Science.

The study indicates that Secretarial Science in China is undergoing a trend of transformation towards interdisciplinary development, internationalization, marketization, comprehensiveness, advanced-degree, and research-orientation. E specially, the transformation of interdisciplinary development and internationalization of Secretarial Science improve the quality of this major and market competiveness. In reality, other disciplines in China are going through similar changes.

In 2011, Beijing International Studies University took the lead in establishing the specialty of International Affairs and International Relations. Afterwards, Jinan University, Beijing language and Culture University, the

\footnotetext{
${ }^{4}$ Qian Shirong explained the point in many papers, and he wrote a book Secretarial System: A Unique Management Auxiliary System on it.

${ }^{5}$ The universities which have the major or direction of Secretary Science are Zhengzhou University, Jinan University, South China Normal University, Guangdong University of Foreign Languages, Jinan University(Zhuhai campus), Quanzhou Normal College, Beijing Youth Politics College, and etc.

${ }^{6}$ Yan Hua said in Proposals on establishment of interdiscipline of Senior Secretaries and Administrative Assistant in 2013, that there are similar Secretary specialty as early as 2005 .
} 
University of Nottingham Ningbo China and other universities opened the majors like the direction of "International Affairs"7 and the major of "International Affairs and International Relations" ${ }^{8}$ under the Diplomacy Studies. The newly-established major of International Affairs, compared with traditional study of international relations is more close to social economy, and more multi-developed with international concern. Besides traditional courses, the new major of International Affairs and International Relations has courses like Foreign-Related Secretary, Foreign Affairs and Etiquettes, Overview of Foreign Affairs Management, which are quite similar to the disciplines of Secretarial Science and Administrative Management. A number of universities added the major of Cultural Industries to the school of Chinese Language and Literature with purpose of keeping pace with the upsurge of cultural industries in China ${ }^{9}$. In addition, a few traditional disciplines have set up many practical and interdisciplinary majors which are suitable for the tendency of marketization and internationalization. The major of Network and New Media in Journalism is a marvelous example.

It can be found that the new trend of the development of Secretarial Science in China accords with the transformation of the society, the requirement from the society of talents with disciplinary, international and comprehensive abilities, and the transformation tendency of higher education in China. However, are all the changes befitting? What problems are there in the transformation? Is it restricted by the limitation of the discipline? Are there any experiences from which other disciplines can learn to pursue innovative development? The thesis will make a comparison between the Secretarial Science in China and the major of "Secretary" in Ewha Womans University. The reason for choosing this university is that the major has a long history, and displays a similar trend of interdiscipline, internationalization and high education ${ }^{10}$.

\section{Experience of Management of Secretary Specialty in South Korea}

In 1968, Secretarial Science, the first secretarial-related major in Korea, was set up by Ewha Womans University. The establishment of this major is closely related to the Korea War, whose aim was to train students who were capable of dealing with English affairs for the government and UNKRA (United Nations Korean Reconstruction Agency), a branch of the United Nation. It met the requirement of domestic situation as a part of special education at that time. The students majoring in Secretary Science at the time should not only be able to take charge of administrative affairs, but also be qualified for assistant secretarial positions. Soon after, many colleges in South Korea set up the major of Secretary, but they were restricted to junior colleges ${ }^{[26]}$. In fact, both the Department of Secretary and the School of Law and Politics ${ }^{11}$ to which it was affiliated were the results of the Korea War. The School of Law and Politics, along with the Department of Law and the Department of Politics and Diplomacy, was founded in 1950, whose goal was to cultivate female talents to deal with juristic, political and diplomatic affairs, or to cultivate teachers to spread these knowledge ${ }^{[27][28]}$. Aiming to satisfy the commercial and economical need from the government, the School of Law and Politics set up the Department of Business in 1963. The title of this department underwent a change from the Department of Commerce and Economy to the Department of Business Administration nowadays ${ }^{12}$. After the Department of Law and the Department of Politics and Diplomacy were separated from the School of law and Politics in 1996, it turned into the School of Business and Economy, and finally became the School of Business Administration in $1999^{[29]}$.

In accordance with the requirement of the society and the government, Ewha Womans University changed the title of "Secretarial Science" to "International Office Administration"13 in 1999, and began to set up the M.A program in 1996 and the $\mathrm{PhD}$ program in 2015. The major of International Office Administration combines the Secretarial Science, International Business and Administrative Affairs together to suit itself better in the rapid trend of economical internalization. Such change was closely associated with the development of IAAP

\footnotetext{
${ }^{7}$ Beijing Normal University and University of Nottingham Ningbo have the major of International Affairs.

${ }^{8}$ Hubei University, Beijing Language and Culture University, University of Nottingham Ningbo, Beijing International Studies University, Dalian University of Foreign Languages have the major of International Affairs and International Relations.

${ }^{9}$ Renmin University of China, Jinan University, Shanghai University of Political Science and Law, and Capital Normal University are good examples.

${ }^{10}$ South Korea is the only country which has Secretary Science for undergraduates or higher degrees

${ }^{11}$ The original title of the School of Law and Politics is College of Law and Political Science.

12 The original title is Department of Commerce, and it changed into Department of Commerce and Economy, and now the title is Department of Business Administration.

${ }^{13}$ It can be implied that Korean government lays high emphasis to English learning. The author was told that Korean high school students should learn another foreign language besides English such as Chinese, Vietnamese, and Spanish, if they want to be admitted to a top university.
} 
(International Authentication Association Professionals) in the United States, and was related to political environment. The Korean government, with the purpose of making Korea the leading position in the globalization trend, required the students to enhance ability of speaking foreign languages, and all walks of the society to hold more international conferences. The purpose of adding directions and courses related to international meetings in the major of International Office Administration was to enhance national soft power of Korea and help the Korean better involved in international affairs. Changing the title of the major to "International Office Administration" was, to a great extent, high concern of the government towards international conferences and exhibitions. In 1998, Ewha Womans University established ICMC ${ }^{14}$, providing cultural, educational, and management support for the advancement of conferences and industrial internalization, and besides, providing a platform for people worldwide to communicate exhibition affairs. At the same time, ICMC also offers consultative service on specialized or global educational management and organization of international conferences ${ }^{[30]}$. So far Ewha Womans University has held a variety of international conferences as the host or the co-organizer ${ }^{15}$. Besides, the major of International Office Administration in Ewha Womans University are playing the guiding role to lead the development of the discipline, as the titles of Secretarial-related majors have changed in many Korean universities. In addition, some of the titles add "intelligence"", which accords with the highly-developed electronic and information industry in Korea.

The example of Secretarial Science in Ewha Womans University shows that this major in Korea has laid much emphasis on international affairs since its birth, especially during the past twenty years. Nowadays the International Office Administration in Ewha Womans University combines well the idea of internationalization and the theory of interdiscipline, and has constructed a mature disciplinary and theoretical system. The educational objective of this major is to cultivate management experts with highly-comprehensive ability under the background of globalization and informatization, including professional secretaries, experts in office management, project managers, web information managers, public relations experts, international conferences experts, and consultants, etc ${ }^{[31]}$. Five directions are set up in the major of International Office Administration, consisting of Secretary Science, Interpersonal Relations, International Conference and Management, Management of Information System, Business Communication, among which multi-disciplinary knowledge is taught in both Korean English, aiming to improve students' comprehensive ability and good command of English. The employment rate of students in this major is between $80 \%$ and $90 \%$, while the average employment rate of Ewha Womans University is only 50\%, which indicates high market demand promising prospects of secretaries. This major will enable the undergraduates comprehensive ability. After graduation, they will be almost competent in working as intermediate administrative assistants, higher than the starting-point of two-year-college graduates. As for postgraduates, the two-year study can be counted as working experience, and after graduation they will be paid almost as much as undergraduates with two years' working experience. What's more, the postgraduates will truly become "experts" of conference management, quite close to the educational objective of the major. ${ }^{17}$

Above all, it can be concluded that the Secretarial Science in South Korea has been closely related to the international society and the market since it was founded, and the development of the major adapts wonderfully to the trend of internationalization. The structure of courses is quite interdisciplinary. The differences between the major of Secretary Science in Korea and that in China largely result from different historical backgrounds of the two countries. Secretarial Science in South Korea was established under the background of the Korean War, and its advancement is associated with the transformation of international position of Korea as well as quick development of technology. Therefore, the Secretarial Science in Korea continuously adapts itself to the environment and absorbs knowledge from other disciplines to ensure a stable development. The Secretarial Science in China, though born at a peaceful age, is in urgent need for transformation, so it can learn lots of useful experience from the major of International Office Administration at Ewha Womans University.

\footnotetext{
${ }^{14}$ The full name of ICMC is International Convention Management Centre.

${ }^{15}$ It is learnt from the course of International Conference Communication that the author attended at Ewha Womans University, taught by 조혜림.

${ }^{16}$ The "intelligence" in Korea is different from what we understand. It is similar to "information" rather than political and military intelligence. But the author assumes that the birth is partly associated with the international role of South Korea during the Cold War.

${ }^{17}$ The Korean undergraduates majoring International Office Administration at Ewha Womans University prefer to find a job rather than seek for Master's degree directly. The postgraduates are mostly on-job or those who returned to university after working. The full-time postgraduates are largely foreign students, and have shifted their major.
} 


\section{Problems and Reflections of the New Trend of Development of Secretarial Science}

Even though Secretarial Science in China shows positive trend towards internationalization, marketization, interdisciplinary, comprehensiveness and high-degree, a few questions should be explored carefully. Is the trend of high-qualification of the major universal? Does the trend exactly represent the advancement of degrees? Should the major continue this trend?

The fact is, although we have introduced the examples of high-degree advancement of Secretarial Science in China and Korea, it is uncommon around the world. Taking the United States for example, only the two-year community universities have the discipline of Secretary Science. If the students majoring Secretary Science want to pursue further studies after graduation, they often change their majors. The advanced courses of Secretary and Administrative Assistant are usually performed in training institutions. The Secretary in Japan has three types: vocational high schools, the Secretary schools (similar to technical secondary schools) and short-term universities (similar to junior universities). In Korea, only few of the 34 Korean universities have the discipline of Secretary for undergraduates and postgraduates, according to statistics in $2012^{[32]}$.

However, the undergraduates in China have already lost advantages when finding a job, thus an increasing number of undergraduates continue to seek for a Master's degree, hoping to improve their competitiveness, and this trend is extending to doctoral students. But only a small portion of postgraduates and doctoral students are devoted to professional research, though the number of postgraduates and doctoral students are increasing rapidly. And few of them are engaged in research or teaching after graduation. Is it the similar case with the high-degree trend of Secretarial Science? As the discipline is lack of systematic theory, how to ensure successfully cultivate postgraduates and doctoral students? And without solid theoretical foundation, how can the postgraduates choose an effective and reliable research direction to be a real scholar? If the degree of this discipline isn't high in developed countries which have longer history and richer experience, the prospect of the trend of high-degree of the major in China is hard to anticipate.

Even though high-degreed Secretary in universities is uncommon in other counties, it doesn't mean that developing high-degreed Secretary specialty is hardly reasonable. In reality, the high-degreed cultivation does exist in the United States, the European countries and Hong Kong, but they are performed by the society rather than universities. For example, the American Association of Administrative Professionals, which is responsible for educational training and issuing certificates, conducts different secretarial trainings and issues certificates for senior secretaries and administrative assistants of different levels. The trainees are required to receive at least 60 -credit' trainings to keep validity of the certificate ${ }^{[33]}$. Such organization, to some extent, plays the role of universities. The reason why the secretaries are educated basically in universities and are cultivated by the society afterwards lies in strong practicality of the major. Thus, students should receive education both from the universities and the society. In the author's opinion, the high-level development of Secretarial Science in China should learn from experience of foreign universities to encourage systematic education from the society, instead of merely concentrating on university education. Surely it is necessary to enrich and emphasize practical training in universities, but such practice shouldn't be restricted to case study and situational teaching in class. The universities should increase the proportion of interdisciplinary courses and build a suitable curriculum system of Secretary Science. Moreover, the interdisciplinary courses should not consider the discipline of Management and Psychology separately, but combine these disciplines with Secretary to pursue continuous innovation and construction. Meanwhile, professionalization and specialization are the inexorable trend of senior secretaries and administrative assistants, thus the discrimination towards the role of secretaries in China should be removed. The universities and junior colleges need pay many efforts to reconstruct students' consciousness of the professional feature of the job that they are office professionals. The concept of "office professionals" should be built first on the students and the professionals, and then spread among the society. Based upon such common sense, systematical professional education and employment should be improved together.

There are certificate training and institute training ${ }^{18}$ in China. The former is performed by training organizations, while the latter is performed by the "Secretarial Societies" such as Guangdong Secretarial Society, and Zhejiang Secretarial Society, etc. The two main approaches to social secretarial trainings, however, have many problems in actual implementation.

First of all, the level of Secretarial qualification test isn't divided scientifically, and the training requirement is unreasonable. The qualification test sets five grades from the fifth (the lowest) to the second (the highest). However, the requirement of the examinees is relatively low. After a period of training, the undergraduates are

${ }^{18}$ The certificate training here is National Secretarial Professional Training rather than international trainings. 
qualified to take the examination of the third grade, and the postgraduates with two years' working experience can take the examination of the highest grade. Thus, those who are qualified for the test of the third grade and the second grade are quite usual. When the test concentrates on the book and the exams and ignore practice and experience, A man with thirty years' experience and the postgraduates with two years' experience are senior secretaries at the second level. What's more, even if the certificate requires learning credits, there are so many training organizations that can help people finish the course quickly and obtain the certificate in a short period. When they got the certificate, they needn't spend any time on study to keep vitality of the certificate, which also reduces the value of the certificate and consciousness of self improvement for secretaries.

Let's look at the institute training undertaken by different Secretarial Societies. Most of the secretarial societies are incapable of professional training, thus they usually cooperate with social practice and trainings or organize training classes ${ }^{19}$ with the employers, or senior seminars for master's degrees ${ }^{20}$. But the seminars cannot be deemed as society training. It isn't performed by the society or the cooperation of society and the universities, the result is examined by the universities. Even though the seminars invite experienced professionals to give lessons, the main force are the teachers from the universities. Besides, these seminars are open for people with various backgrounds in the approaches of big class. The students are not divided according to their working experience and educational backgrounds, thus the educational objectives cannot be ensured.

To sum up, Secretarial science in china is undergoing a trend of transformation towards openness, marketization, high-qualified and interdisciplinary. If we explore into the theoretical discussion of the discipline, learn from the other countries, and improve the combination of university training and professional trainings from the society, the discipline will be successfully innovated. However, as the congenial deficiencies in China, the transformation will be difficult, and need us to work together.

\section{References}

[1][25] Chen Heyi. (2012). Secretary Science. Guangzhou: Jinan University Press.

[2] Chinese Ministry of Education. The Undergraduate Specialty Catalogue of Higher Education (2012)[EB/OL]. http://www.moe.edu.cn/ewebeditor/uploadfile/2012/10/12/20121012084054830.doc. 35.

[3] Wang Shoufu. (2014). Main Problems and Reform Measures of Professional Education of Secretarial Science. Secretary, (10), 7-11.

[4] Chinese Ministry of Education. The Record and Examination Result of the Undergraduate Majors of Higher Education. (2012, 2013, 2014, 2015). [EB/OL]. http://moe.gov.cn

[5] Lv Shaohua. (1986). Secretarial Work from the Perspective of Psychology. Secretaries' Companion, (1), 8-9.

[6] Zhao Zhongli. (1988). Primary Study of Secretarial Psychology. Secretaries' Companion, (11), 17-18.

[7] Zhang Qinping. (1990). Secretarial Psychology. Hefei: Anhui Literature and Art Publishing House.

[8] Zhao Zhongli. (2004). Modern Secretarial Psychology. Beijing: Higher Education Press.

[9] Zheng Jianer (editor). (2013). Secretarial Science. Shanghai: East China Normal University Press.

[10] Hou Lu. (2013). On Construction of Practical Teaching of Secretarial Psychology Courses. Heilongjiang: Journal of Heilongjiang College of Education, (5), 104-105.

[11] Lu Yufang. (2014). Psychological Interpretation of Relationship Between the Boss and The Secretary. Secretary, (9), 19-20.

[12] Han Miaomiao. (2015). Application of EQ to Secretarial Works. Guangzhou: Jinan University.

[13][16][24] Long Yin. (2010). Secretarial Science in China Under the Background of Globalization. In Yan Hua (Ed.), Senior Secretary and Administrative Assistant (1st ed., pp. 1-10). Guangzhou: Jinan University Press.

[14] Li Li. (2013). Secretarial Science Has Attributes of Management-Written When Secretarial Science Become An Independent Discipline. Archival Science Report, (2), 32-35.

[15] Qian Shirong. (1999). Research on Core Theory of Secretarial Science. Secretary, (9), 11-17.

\footnotetext{
${ }_{19}$ The formal trainings here don't refer to the training courses provided by the society to pass the entrance exams of Master's program and certificate exams. They are formal local seminars or university seminars.

${ }^{20}$ The senior seminars for people on the job are different from the Masters' degree by postgraduates. Those who attend the senior seminars don't need to take the entrance exam, and get the graduation certificate after completing the courses and the graduation thesis. If they want to get a diploma, they should take similar entrance exam for a Master's degree.
} 
[17] Zheng Miaojie. (2012). Servant Obedience Theory and Consciousness of Obedience of Secretaries. Guangzhou: Jinan University.

[18] Guo Yuan. (2013). On the Art of Time Management of Secretaries. Guangzhou: Jinan University.

[19] Lu Yufang. (2014). Psychological Interpretation of the Relationship between the Boss and the Secretary. Secretary, (9), 19-20.

[20] Ning Maochang, \& Sun Xinguang. The Research Objects, Methods, and Significance of Secretarial Sociology. Journal of Shandong Normal University (Social Science), (6), 24-28.

[21] Qian Shirong. (2000). Research on the Structure of Secretarial Science. Secretary, (6), 9-11.

[22] Feng Shizheng. (2003). Power, Relation, and Resources in the Transition-an Sociological Analysis of "Corruption of Secretaries". Jiangsu Social Sciences, (6), 84-89.

[23] Huan Lei. (2013). On Political Elite Secretarial Powers in Modern China. Shanghai: Fudan University.

[26][32] Historical Events of Secretarial Science at Junior Universities). 2013(6):13-14, 18, 21-23. (the author doesn't know Korean, so it was translated by others)

[27] History of Ewha Law School [EB/OL]. http://law.ewha.ac.kr/en/?page_id=21.

[28] Ewha College of Social Science. History of Political Science \& International Relations [EB/OL]. http://www.ewha.ac.kr/mbs/ewhaen/jsp/organizationCon/organizationView2.jsp?id=ewhaen_030202010000 \&cateId $=67 \&$ lan $=$ eng.

[29] History of Ewha School of Business [EB/OL]. http://biz.ewha.ac.kr/eng/esb/history.

[30] Ewha International Convention Management Center (Introduction) [EB/OL]. https://www.ewhaconvention.net:50013/main.asp.

[31] Ewha Womans University. The Department of International Office Administration in the School of Business Administration[EB/OL]. http://www.ewha.ac.kr/mbs/ewhacn/subview.jsp?id=ewhacn_030108000000.

[33] International Association of Administrative Professionals. Certification Policies \& Procedures Handbook 2016 [EB/OL]. http://c.ymcdn.com/sites/www.iaap-hq.org/resource/resmgr/docs/certification_pdf/iaapexam-handbook-new.pdf.

[34] China Vocational Information Committee. Qualification Test of Secretaries. [EB/OL]. http://www.conet.org.cn/module/occupational/indexOccupationalChildOne.do?pfnproId=20529\&pfntplId= 1023\#maodiang-pfnproId-20529-1024.

[35] Xiao Hongzhen. (2014). Study on Standardization of Professional Training of Secretaries. Guangzhou: Jinan University.

\section{Copyrights}

Copyright for this article is retained by the author(s), with first publication rights granted to the journal.

This is an open-access article distributed under the terms and conditions of the Creative Commons Attribution license (http://creativecommons.org/licenses/by/4.0/). 